\title{
Hepatitis B and C surveillance and screening programmes in the non-EU/EEA Member States of the WHO European Region: survey findings from 10 countries, 2012
}

A Mozalevskis ${ }^{1}$, I Eramova ${ }^{1}$, K Safreed-Harmon ${ }^{2}$, JV Lazarus ${ }^{2}$

1. World Health Organization (WHO) Regional Office for Europe, Copenhagen, Denmark

2. CHIP, Centre for Health and Infectious Disease Research and WHO Collaborating Centre on HIV and Viral Hepatitis, Rigshospitalet, University of Copenhagen, Denmark

Correspondence: Jeffrey V. Lazarus (Jeffrey.Lazarus@regionh.dk)

Citation style for this article:

Mozalevskis A, Eramova I, Safreed-Harmon K, Lazarus JV. Hepatitis B and C surveillance and screening programmes in the non-EU/EEA Member States of the WHO European Region: survey findings from 10 countries, 2012. Euro Surveill. 2016;21(22):pii=30245. DOI: http://dx.doi.org/10.2807/1560-7917.ES.2016.21.22.30245

The hepatitis B virus (HBV) and hepatitis C virus (HCV) epidemics warrant a comprehensive response based on reliable population-level information about transmission, disease progression and disease burden, with national surveillance systems playing a major role. In order to shed light on the status of surveillance in countries of the World Health Organization (WHO) European Region outside of the European Union and European Economic Area (EU/EEA), we surveyed 18 countries in Central and Eastern Europe. Among the 10 countries that responded, the common features of many surveillance systems included mandatory surveillance, passive case-finding and the reporting of both acute and chronic HBV and HCV. Only some countries had surveillance systems that incorporated the tracking of associated conditions and outcomes such as cirrhosis and liver transplantation. Screening programmes for some key populations appeared to be in place in many countries, but there may be gaps in relation to screening programmes for people who inject drugs, prisoners, sex workers and men who have sex with men. Nonetheless, important components of a surveillance structure are in place in the responding study countries. It is advisable to build on this structure to develop harmonised HBV and HCV surveillance for all 53 Member States of the WHO European Region following the example of the system recently instituted in EU/EEA countries.

\section{Introduction}

Hepatitis B virus (HBV) and hepatitis C virus (HCV) infections can result in acute and chronic hepatitis and are major public health problems in many parts of the world. Together they are thought to cause more than 1.4 million deaths per year worldwide, mostly due to chronic hepatitis sequelae such as liver cirrhosis and liver cancer [1]. In the World Health Organization (WHO) European Region, an estimated 1.8 per cent of adults are chronically infected with hepatitis $B$; moreover hepatitis C RNA (HCV RNA) prevalence is estimated to be 2.0 per cent. The eastern part of the Region is disproportionally affected, whereby two-thirds of those infected with HBV or HCV live outside of the European Union (EU) and European Free Trade Association [2]. Throughout the Region, there is evidence of high levels of HCV infection and to a lesser extent HBV infection in populations of people who inject drugs (PWID) [3]. Other notable transmission pathways for hepatitis B in Europe include sexual intercourse, both heterosexual and among men who have sex with men (MSM), and nosocomial transmission in some countries. Available epidemiological evidence on HBV and HCV in migrant populations suggests that in several European countries, many migrant groups are disproportionately affected $[4,5]$. However, precise data on disease burden and changing trends are lacking in most countries [6], and information on existing viral hepatitis surveillance systems and screening practices is not available at the regional level.

WHO defines public health surveillance as the continuous, systematic collection, analysis and interpretation of health-related data needed for the planning, implementation, and evaluation of public health practice' [7]. Surveillance of diseases and health conditions is important for guiding decision-making about how health systems should be configured at the subnational, national, regional and global levels. A key principle of surveillance is that the surveillance system should be designed to address the specific public health objectives at hand [8]. In the case of HBV and $\mathrm{HCV}$, this principle suggests a need for surveillance 
TABLE 1

Respondent and non-respondent countries to a survey on hepatitis B and C surveillance and screening programmes, 2012

\section{Responded to survey $(\mathrm{n}=10) \quad$ Did not respond to survey $(\mathrm{n}=8)$}

\begin{tabular}{l|l}
\hline Armenia; Azerbaijan; & Albania; Bosnia and Herzegovina;
\end{tabular} Belarus; Croatia; Kyrgyzstan; Bulgaria; Kazakhstan; Serbia;

Moldova; Montenegro;

Russia; Tajikistan; Ukraine the former Yugoslav Republic of Macedonia; Turkey; Uzbekistan

systems with the capacity to capture and synthesise a complex array of data on disease transmission and progression. This is difficult, since both diseases manifest in ways that can make it highly challenging to track incidence, prevalence, morbidity, mortality and the impact of prevention and treatment interventions $[9,10]$.

In 2006, the European Parliament directed the European Centre for Disease Prevention and Control (ECDC) to prioritise the harmonisation of viral hepatitis surveillance in the EU [11]. In the course of this work, ECDC conducted a survey in 2009 to gather information about various features of national surveillance systems in the EU and European Economic Area (EEA) such as the types of surveillance conducted and the types of data collected [12]. Information of this nature is valuable for interpreting surveillance findings and for assessing how surveillance systems can be further strengthened and harmonised. No comparable studies have been conducted to assess the characteristics of viral hepatitis surveillance systems and screening programmes in European countries outside of the EU/EEA.

The following paper presents findings from a survey conducted by the WHO Regional Office for Europe among mostly non-EU/EEA Member States in Central and Eastern Europe, including Central Asia.

\section{Methods}

In 2012, the WHO Regional Office for Europe conducted a survey on viral hepatitis surveillance in 17 non-EU/ EEA Member States comprising Albania, Armenia, Azerbaijan, Belarus, Bosnia and Herzegovina*, Croatia, Kazakhstan, Kyrgyzstan, Moldova, Montenegro, Russia, Serbia, Tajikistan, the former Yugoslav Republic of Macedonia, Turkey, Ukraine and Uzbekistan. In addition, Bulgaria was included. These countries were selected because little is known about their current practices. In each country, the person recognised by WHO via the respective ministry of health as the governmental focal point for viral hepatitis surveillance was asked to complete the survey.

The survey consisted of 20 questions relating to HBV and HCV surveillance systems, case definitions and populations screened for hepatitis. Respondents also had the option of providing comments. The survey was developed in English by one of this paper's co-authors who, as a native Russian speaker, ensured correct translation of the questionnaire into Russian. Englishand Russian-language versions of the survey were distributed via email to the country focal points. Data collection took place between 1 July and 31 August 2012 and there was one reminder sent midway through the data collection period to increase the response rate.

For the purpose of this study, and with a secondary aim of comparing the findings from non-EU/EEA countries with the findings from the 2009 ECDC survey [12], we selected 10 of the questions, which covered objectives and main features of viral hepatitis surveillance systems; types of data collected through viral hepatitis case reporting; and data linkages with the associated conditions and populations screened for HBV and HCV. For nine of the questions (which are further detailed in a table within the result section), respondents were instructed to tick check-boxes to indicate their answers. The tenth question asked 'Which of the following populations, if any, are screened for hepatitis?' and was followed by check-boxes for 18 options identified. These options and responses are also further detailed in a separate table in the results. One of these options was 'Other groups - please specify', and space was provided for respondents to report this information. Simple definitions of terms such as 'population-based surveillance' and 'active surveillance' were incorporated into survey questions. All survey responses were entered into Microsoft Excel and a descriptive analysis was performed.

\section{Results}

\section{Respondents}

Completed surveys were received from focal points in 10 of 18 countries as described in Table 1 . During the time of this study, all respondent countries were WHO European Region Member States, which were not part of the EU/EEA.

\section{Surveillance objectives}

All 10 survey respondents indicated that the objectives of HBV and HCV surveillance systems included monitoring trends and detecting outbreaks. Most stated that the goals were also to monitor changes in disease distribution ( $n=9$ countries) and identify at-risk populations ( $n=8$ for HBV; $n=7$ for HCV) (Table 2). Fewer respondents reported planning and evaluating control measures ( $n=7$ for $\mathrm{HBV}$; $n=6$ for $\mathrm{HCV}$ ), identifying research needs ( $n=3$ for both diseases) and improving epidemiological knowledge as specific surveillance objectives $(n=6)$. 


\section{TABLE 2A}

Hepatitis surveillance system features of 10 non-European Union/European Economic Area Member States of the World Health Organization European Region, 2012

\begin{tabular}{|c|c|c|}
\hline Characteristics of the surveillance system & $\begin{array}{l}\text { HBV } \\
\text { Number of countries responding } \\
\text { (names of respondent countries) }\end{array}$ & $\begin{array}{l}\text { HCV } \\
\text { Number of countries responding } \\
\text { (names of respondent countries) }\end{array}$ \\
\hline \multicolumn{3}{|c|}{ What are the objectives of the surveillance system? } \\
\hline Monitor trends & $\begin{array}{c}10 \\
\text { (Armenia, Azerbaijan, Belarus, Croatia, Kyrgyzstan, Moldova, } \\
\text { Montenegro, Russia, Tajikistan, Ukraine) }\end{array}$ & $\begin{array}{c}10 \\
\text { (Armenia, Azerbaijan, Belarus, Croatia, } \\
\text { Kyrgyzstan, Moldova, Montenegro, Russia, } \\
\text { Tajikistan, Ukraine) }\end{array}$ \\
\hline Detect outbreaks & $\begin{array}{c}10 \\
\text { (Armenia, Azerbaijan, Belarus, Croatia, Kyrgyzstan, Moldova, } \\
\text { Montenegro, Russia, Tajikistan, Ukraine) }\end{array}$ & $\begin{array}{c}9 \\
\text { (Armenia, Azerbaijan, Belarus, Croatia, } \\
\text { Kyrgyzstan, Moldova, Montenegro, Russia, } \\
\text { Ukraine) }\end{array}$ \\
\hline Monitor changes in disease distribution & $\begin{array}{c}9 \\
\text { (Armenia, Azerbaijan, Belarus, Croatia, Kyrgyzstan, } \\
\text { Montenegro, Russia, Tajikistan, Ukraine) }\end{array}$ & $\begin{array}{c}9 \\
\text { (Armenia, Azerbaijan, Belarus, Croatia, } \\
\text { Kyrgyzstan, Montenegro, Russia, Tajikistan, } \\
\text { Ukraine) }\end{array}$ \\
\hline Plan and evaluate control measures & $\begin{array}{c}\text { (Armenia, Kyrgyzstan, Montenegro, Moldova, Russia, } \\
\text { Tajikistan, Ukraine) }\end{array}$ & $\begin{array}{c}6 \\
\text { (Armenia, Kyrgyzstan, Montenegro, Moldova, } \\
\text { Russia, Ukraine) }\end{array}$ \\
\hline $\begin{array}{l}\text { Identify research needs and facilitate } \\
\text { research }\end{array}$ & $\begin{array}{c}3 \\
\text { (Armenia, Montenegro, Moldova) }\end{array}$ & $\begin{array}{c}3 \\
\text { (Armenia, Montenegro, Moldova) }\end{array}$ \\
\hline Improve knowledge of epidemiology & $\begin{array}{c}6 \\
\text { (Armenia, Montenegro, Moldova, Russia, Tajikistan, Ukraine) }\end{array}$ & $\begin{array}{c}6 \\
\text { (Armenia, Montenegro, Moldova, Russia, } \\
\text { Tajikistan, Ukraine) }\end{array}$ \\
\hline Identify at-risk populations & $\begin{array}{c}8 \\
\text { (Armenia, Azerbaijan, Belarus, Montenegro, Moldova, Russia, } \\
\text { Tajikistan, Ukraine) }\end{array}$ & $\begin{array}{l}7 \\
\text { (Armenia, Belarus, Montenegro, Moldova, } \\
\text { Russia, Tajikistan, Ukraine) }\end{array}$ \\
\hline Other (please comment) & 0 & 0 \\
\hline \multicolumn{3}{|c|}{ In your country, what is the legal basis of hepatitis reporting? } \\
\hline Mandatory ${ }^{\mathrm{a}}$ & 10 & 10 \\
\hline Voluntary $^{\mathrm{a}}$ & 0 & o \\
\hline \multicolumn{3}{|c|}{ Would you describe your surveillance system as active or passive? } \\
\hline $\begin{array}{l}\text { Active - the proactive searching for case } \\
\text { reports from the population }\end{array}$ & 0 & o \\
\hline $\begin{array}{l}\text { Passive - the passive receiving of case } \\
\text { reports from surveillance structures within } \\
\text { the population }\end{array}$ & $\begin{array}{c}9 \\
\text { (Armenia, Azerbaijan, Belarus, Croatia, Kyrgyzstan, } \\
\text { Montenegro, Moldova, Tajikistan, Ukraine) }\end{array}$ & $\begin{array}{c}9 \\
\text { (Armenia, Azerbaijan, Belarus, Croatia, } \\
\text { Kyrgyzstan, Montenegro, Moldova, Tajikistan, } \\
\text { Ukraine) }\end{array}$ \\
\hline Depends on type of surveillance & 0 & 0 \\
\hline \multicolumn{3}{|c|}{ Which of the following surveillance methods are used? } \\
\hline Population-based (all cases reported) & 10 & 10 \\
\hline $\begin{array}{l}\text { Risk group-based (occupational or } \\
\text { behavioural risk group monitoring) }\end{array}$ & $\begin{array}{c}\text { (Armenia, Belarus, Croatia, Moldova, Russia, Tajikistan, } \\
\text { Ukraine) }\end{array}$ & $\begin{array}{c}6 \\
\text { (Armenia, Belarus, Croatia, Moldova, Russia, } \\
\text { Tajikistan) }\end{array}$ \\
\hline $\begin{array}{l}\text { Sentinel (all cases from selected reporting } \\
\text { sites) }\end{array}$ & 0 & $\stackrel{1}{\text { (Tajikistan) }}$ \\
\hline Other (surveys, anonymous sampling, etc.) & $\stackrel{3}{3}$ (Croatia, Russia, Ukraine) & $\stackrel{3}{3}$ (Croatia, Russia, Ukraine) \\
\hline \multicolumn{3}{|l|}{ What types of cases are included in surveillance? } \\
\hline Acute $^{a}$ & 10 & 10 \\
\hline Chronic $^{\mathrm{a}}$ & $\begin{array}{c}8 \\
\text { (Belarus, Croatia, Kyrgyzstan, Montenegro, Moldova, Russia, } \\
\text { Tajikistan, Ukraine) }\end{array}$ & $\begin{array}{c}8 \\
\text { (Belarus, Croatia, Kyrgyzstan, Montenegro, } \\
\text { Moldova, Russia, Tajikistan, Ukraine) }\end{array}$ \\
\hline Asymptomatic & (Belarus, Croatia, Russia) & ${ }^{2}{ }^{2}$ Croatia, Russia) \\
\hline Suspected & (Armenia, Croatia, Russia) & (Armenia, Croatia, Russia) \\
\hline Hepatitis (undefineda) & (Azerbaijan, Belarus, Croatia, Montenegro, Ukraine) & $\begin{array}{c}\text { (Azerbaijan, Belarus, Croatia, Montenegro, } \\
\text { Ukraine) }\end{array}$ \\
\hline Other (please comment) & o & o \\
\hline
\end{tabular}

HBV: hepatitis B virus; HCV: hepatitis C virus; HIV: human immunodeficiency virus.

a This term was not defined and its interpretation was at the discretion of the survey respondent. 


\section{TABLE 2B}

Hepatitis surveillance system features of 10 non-European Union/European Economic Area Member States of the World Health Organization European Region, 2012

\begin{tabular}{|c|c|c|}
\hline Characteristics of the surveillance system & $\begin{array}{l}\text { HBV } \\
\text { Number of countries responding } \\
\text { (names of respondent countries) }\end{array}$ & $\begin{array}{l}\text { HCV } \\
\text { Number of countries responding } \\
\text { (names of respondent countries) }\end{array}$ \\
\hline \multicolumn{3}{|c|}{ What case classifications are included in surveillance? } \\
\hline Probable $^{a}$ & (Armenia, Croatia, Russia) & (Armenia, Croatia, Russia) \\
\hline Confirmed $^{a}$ & $\begin{array}{c}9 \\
\text { (Armenia, Azerbaijan, Belarus, Croatia, Kyrgyzstan, } \\
\text { Montenegro, Russia, Tajikistan, Ukraine) }\end{array}$ & $\begin{array}{c}9 \\
\text { (Armenia, Azerbaijan, Belarus, Croatia, } \\
\text { Kyrgyzstan, Montenegro, Russia, Tajikistan, } \\
\text { Ukraine) }\end{array}$ \\
\hline Epidemiologically linked & $\begin{array}{c}4 \\
\text { (Azerbaijan, Belarus, Moldova, Russia) }\end{array}$ & $\begin{array}{c}4 \\
\text { (Azerbaijan, Belarus, Moldova, Russia) }\end{array}$ \\
\hline Other classification (please comment) & o & o \\
\hline \multicolumn{3}{|c|}{ Which of the following demographic data are collected (if any)? } \\
\hline $\begin{array}{l}\text { Patient identifier, address, sex, occupation, } \\
\text { birth date, place of birth }\end{array}$ & $\begin{array}{c}9 \\
\text { (Armenia, Azerbaijan, Belarus, Croatia, Montenegro, Moldova, } \\
\text { Russia, Tajikistan, Ukraine) }\end{array}$ & $\begin{array}{c}9 \\
\text { (Armenia, Azerbaijan, Belarus, Croatia, } \\
\text { Montenegro, Moldova, Russia, Tajikistan, } \\
\text { Ukraine) }\end{array}$ \\
\hline Pregnancy status & (Armenia, Azerbaijan, Moldova, Russia, Tajikistan) & $\begin{array}{c}5 \\
\text { (Armenia, Azerbaijan, Moldova, Russia, } \\
\text { Tajikistan) }\end{array}$ \\
\hline Ethnic group & ${ }^{2}$ (Armenia, Moldova) & ${ }^{2}{ }^{2}$ (Armenia, Moldova) \\
\hline Country in which infection was acquired & 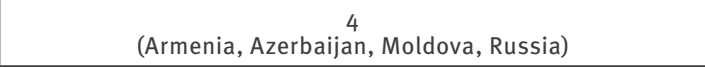 & $\begin{array}{c}4 \\
\text { (Armenia, Azerbaijan, Moldova, Russia) }\end{array}$ \\
\hline Date of onset & $\begin{array}{c}8 \\
\text { (Armenia, Azerbaijan, Belarus, Croatia, Montenegro, Moldova, } \\
\text { Russia, Ukraine) }\end{array}$ & $\begin{array}{c}8 \\
\text { (Armenia, Azerbaijan, Belarus, Croatia, } \\
\text { Montenegro, Moldova, Russia, Ukraine) }\end{array}$ \\
\hline Date of diagnosis & $\begin{array}{c}8 \\
\text { (Armenia, Azerbaijan, Belarus, Montenegro, Moldova, Russia, } \\
\text { Tajikistan, Ukraine) }\end{array}$ & $\begin{array}{c}8 \\
\text { (Armenia, Azerbaijan, Belarus, Montenegro, } \\
\text { Moldova, Russia, Tajikistan, Ukraine) }\end{array}$ \\
\hline Date of reporting & $\begin{array}{c}8 \\
\text { (Armenia, Azerbaijan, Belarus, Croatia, Montenegro, Moldova, } \\
\text { Russia, Tajikistan) }\end{array}$ & $\begin{array}{c}8 \\
\text { (Armenia, Azerbaijan, Belarus, Croatia, } \\
\text { Montenegro, Moldova, Russia, Tajikistan) }\end{array}$ \\
\hline \multicolumn{3}{|c|}{ Which of the following classification data are collected from cases? } \\
\hline Clinical symptoms & $\begin{array}{c}6 \\
\text { (Armenia, Azerbaijan, Belarus, Moldova, Russia, Ukraine) }\end{array}$ & $\begin{array}{c}6 \\
\begin{array}{c}\text { (Armenia, Azerbaijan, Belarus, Moldova, Russia, } \\
\text { Ukraine) }\end{array}\end{array}$ \\
\hline Laboratory results & $\begin{array}{c}8 \\
\text { (Armenia, Azerbaijan, Belarus, Montenegro, Moldova, Russia, } \\
\text { Tajikistan, Ukraine) }\end{array}$ & $\begin{array}{c}8 \\
\text { (Armenia, Azerbaijan, Belarus, Montenegro, } \\
\text { Moldova, Russia, Tajikistan, Ukraine) }\end{array}$ \\
\hline Epidemiological information ${ }^{a}$ & $\begin{array}{c}9 \\
\text { (Armenia, Azerbaijan, Belarus, Croatia, Montenegro, Moldova, } \\
\text { Russia, Tajikistan, Ukraine) }\end{array}$ & $\begin{array}{c}99 \\
\text { (Armenia, Azerbaijan, Belarus, Croatia, } \\
\text { Montenegro, Moldova, Russia, Tajikistan, } \\
\text { Ukraine) }\end{array}$ \\
\hline \multicolumn{3}{|c|}{ For which of the following associated conditions is case data linked to/collected? } \\
\hline Liver transplant & $\stackrel{3}{3}$ (Armenia, Belarus, Moldova) & (Armenia, Belarus, Moldova) \\
\hline Liver cancer & ${ }^{2}{ }^{4}$ Armenia, Kyrgyzstan, Moldova, Tajikistan) & $\begin{array}{c}{ }^{4} \\
\text { (Armenia, Kyrgyzstan, Moldova, Tajikistan) }\end{array}$ \\
\hline HBV or HCV coinfection & $\begin{array}{c}6 \\
\text { (Armenia, Azerbaijan, Belarus, Kyrgyzstan, Moldova, } \\
\text { Tajikistan) }\end{array}$ & $\begin{array}{c}6 \\
\text { (Armenia, Azerbaijan, Belarus, Kyrgyzstan, } \\
\text { Moldova, Tajikistan) }\end{array}$ \\
\hline HIV coinfection & $\begin{array}{c}6 \\
\begin{array}{c}\text { (Armenia, Azerbaijan, Belarus, Kyrgyzstan, Moldova, } \\
\text { Tajikistan) }\end{array}\end{array}$ & $\begin{array}{c}6 \\
\text { (Armenia, Azerbaijan, Belarus, Kyrgyzstan, } \\
\text { Moldova, Tajikistan) }\end{array}$ \\
\hline Hepatitis-associated mortality & (Armenia, Belarus, Kyrgyzstan, Moldova, Tajikistan) & $\begin{array}{c}5 \\
\text { (Armenia, Belarus, Kyrgyzstan, Moldova, } \\
\text { Tajikistan) }\end{array}$ \\
\hline
\end{tabular}

HBV: hepatitis B virus; HCV: hepatitis C virus; HIV: human immunodeficiency virus.

a This term was not defined and its interpretation was at the discretion of the survey respondent. 


\section{TABLE 3}

Populations screened in 10 non-European Union/European Economic Area Member States of the World Health Organization European Region, 2012

\begin{tabular}{|c|c|c|}
\hline Population & $\begin{array}{c}\text { HBV } \\
\text { Number of countries responding } \\
\text { (names of respondent countries) }\end{array}$ & $\begin{array}{l}\text { HCV } \\
\text { Number of countries responding } \\
\text { (names of respondent countries) }\end{array}$ \\
\hline People who inject drugs & (Belarus, Croatia, Moldova, Russia, Ukraine) & $\begin{array}{c}\text { (Belarus, Croatia, Moldova, Russia, } \\
\text { Ukraine) }\end{array}$ \\
\hline Contacts of infected people who inject drugs & ${ }^{2}$ (Belarus, Croatia) & ${ }^{2}$ (Belarus, Croatia) \\
\hline Sex workers & 0 & 0 \\
\hline Men who have sex with men & 0 & 0 \\
\hline Inmates in closed settings & ${ }^{2}{ }^{2}$ (Croatia, Russia) & ${ }^{2}{ }^{2}$ (Croatia, Russia) \\
\hline People living with HIV & $\begin{array}{c}8 \\
\text { (Armenia, Azerbaijan, Belarus, Croatia, } \\
\text { Kyrgyzstan, Montenegro, Moldova, Russia) }\end{array}$ & $\begin{array}{c}9 \\
\text { (Armenia, Azerbaijan, Belarus, Croatia, } \\
\text { Kyrgyzstan, Montenegro, Moldova, Russia, } \\
\text { Tajikistan) }\end{array}$ \\
\hline Transfusion/organ transplant recipients & $\begin{array}{c}7 \\
\text { (Armenia, Azerbaijan, Belarus, Croatia, } \\
\text { Moldova, Russia, Ukraine) }\end{array}$ & $\begin{array}{c}7 \\
\text { (Armenia, Azerbaijan, Belarus, Croatia, } \\
\text { Moldova, Russia, Ukraine) }\end{array}$ \\
\hline HBV- or HCV-infected patients & $\begin{array}{c}8 \\
\text { (Armenia, Azerbaijan, Belarus, Croatia, } \\
\text { Montenegro, Moldova, Russia, Ukraine) }\end{array}$ & $\begin{array}{c}8 \\
\text { (Armenia, Azerbaijan, Belarus, Croatia, } \\
\text { Montenegro, Moldova, Russia, Ukraine) }\end{array}$ \\
\hline Persons born in endemic areas & $\begin{array}{c}1 \\
\text { (Moldova) }\end{array}$ & $\begin{array}{c}1 \\
\text { (Moldova) }\end{array}$ \\
\hline Blood and organ donors & 10 & 10 \\
\hline Hospitalised patients/pre-operative patients & $\begin{array}{c}7 \\
\text { (Armenia, Kyrgyzstan, Montenegro, Moldova, } \\
\text { Russia, Tajikistan, Ukraine) }\end{array}$ & $\begin{array}{c}7 \\
\text { (Armenia, Kyrgyzstan, Montenegro, } \\
\text { Moldova, Russia, Tajikistan, Ukraine) }\end{array}$ \\
\hline $\begin{array}{l}\text { Persons who require immunosuppressive } \\
\text { therapy }\end{array}$ & $\stackrel{3}{3}$ (Armenia, Croatia, Moldova) & (Armenia, Croatia, Moldova) \\
\hline Pregnant women & $\begin{array}{c}9 \\
\text { (Armenia, Azerbaijan, Belarus, Croatia, } \\
\text { Kyrgyzstan, Montenegro, Moldova, Russia, } \\
\text { Ukraine) }\end{array}$ & $\begin{array}{c}6 \\
\text { (Azerbaijan, Belarus, Kyrgyzstan, } \\
\text { Montenegro, Moldova, Russia) }\end{array}$ \\
\hline Family members & $\begin{array}{c}8 \\
\text { (Armenia, Belarus, Croatia, Kyrgyzstan, } \\
\text { Montenegro, Moldova, Russia, Ukraine) }\end{array}$ & $\begin{array}{c}6 \\
\text { (Armenia, Belarus, Kyrgyzstan, } \\
\text { Montenegro, Moldova, Russia) }\end{array}$ \\
\hline Sexual contacts of infected persons & $\stackrel{3}{3}$ (Armenia, Croatia, Moldova) & $\stackrel{3}{3}$ (Armenia, Croatia, Moldova) \\
\hline Haemodialysis patients & $\begin{array}{c}9 \\
\text { (Armenia, Azerbaijan, Belarus, Croatia, } \\
\text { Montenegro, Moldova, Russia, Tajikistan, } \\
\text { Ukraine) }\end{array}$ & $\begin{array}{c}8 \\
\text { (Armenia, Azerbaijan, Belarus, Croatia, } \\
\text { Montenegro, Moldova, Russia, Tajikistan) }\end{array}$ \\
\hline $\begin{array}{l}\text { Exposed healthcare, public safety, and } \\
\text { emergency medical workers }\end{array}$ & 10 & $\begin{array}{c}8 \\
\text { (Armenia, Belarus, Croatia, Kyrgyzstan, } \\
\text { Montenegro, Moldova, Russia, Tajikistan) }\end{array}$ \\
\hline Other groups - please specify & (Kyrgyzstan, Moldova, Tajikistan) & (Kyrgyzstan, Moldova, Tajikistan) \\
\hline
\end{tabular}

HBV: hepatitis B virus; HCV: hepatitis C virus; HIV: human immunodeficiency virus.

\section{Surveillance system characteristics}

All 10 countries reported that their surveillance systems for HBV and HCV were mandatory rather than voluntary, and nine characterised the surveillance systems as passive rather than active (Table 2). Surveillance systems in all 10 countries reportedly employed population-based methods, and in several countries there was risk group-based surveillance as well $(n=7$ for $\mathrm{HBV}$ and $\mathrm{n}=6$ for HCV). The only country that reported carrying out sentinel surveillance was Tajikistan (for hepatitis $($ but not hepatitis $B)$. All countries reported including acute HBV and HCV cases in surveillance, and all but two countries (Armenia and Azerbaijan) reported including chronic cases as well. Five respondents indicated that 'undefined' hepatitis cases were included in surveillance. Nine countries reported including 'confirmed' cases in surveillance, and three of those countries (Armenia, Croatia and Russia) also included 'probable' cases. 


\section{Data collected}

Most responding countries $(n=9)$ collected case-based demographic data such as patient identifier, address, sex, occupation, and time and place of birth and epidemiological data (Table 2). Among these, eight countries also collected laboratory results, and six clinical symptoms. Four countries collected data on the country in which infection was acquired, and two countries (Armenia and Moldova) collected information on the ethnic identity of infected individuals. Six countries reported collecting or linking to information about human immunodeficiency virus (HIV) coinfection and $\mathrm{HBV} / \mathrm{HCV}$ coinfection, while smaller numbers of countries reported doing so for liver transplant $(n=3$ for both diseases), liver cancer ( $n=4$ for both diseases) and hepatitis-associated mortality $(n=5$ for both diseases).

\section{Populations screened}

All 10 countries reported screening blood and organ donors for both HBV and HCV (Table 3). All countries with the exception of Tajikistan reported screening pregnant women for HBV, and in six countries pregnant women were screened for HCV as well. Other populations screened in most countries included people living with HIV ( $n=8$ for HBV; $n=9$ for HCV), haemodialysis patients $(n=9$ for $\mathrm{HBV} ; \mathrm{n}=8$ for $\mathrm{HCV}$ ), and exposed healthcare workers, emergency medical workers and public safety workers ( $n=10$ for HBV; $n=8$ for HCV). Five countries reported screening PWID for both HBV and HCV. Only two countries reported screening inmates in closed settings (Croatia and Russia, for both diseases). One reported screening persons born in endemic areas (Moldova, for both HBV and HCV), and three, screening sexual contacts of infected persons (Armenia, Croatia and Russia, for both diseases). There were no countries in which sex workers or MSM were among the populations screened.

\section{Discussion}

This is the first survey that provides an overview of surveillance systems and screening programmes for viral hepatitis $B$ and $C$ in selected countries of the WHO European Region outside of the EU/EEA. Across the 10 countries that responded to our survey, common features of many national surveillance systems included mandatory surveillance, passive case-finding and the reporting of both acute and chronic HBV and HCV. The objectives of the surveillance systems were mostly similar among responding countries. There was considerable variation in the type and amount of data collected across countries; however, basic demographic, epidemiological and clinical data were reportedly collected in the majority of responding countries. Populations screened in most countries included blood and organ donors, pregnant women, people living with $\mathrm{HIV}$, haemodialysis patients and people at risk of occupational exposure.

Similar to the ECDC's 2009 survey of HBV and HCV surveillance in EU/EEA countries, we found that chronic disease surveillance lagged behind acute disease surveillance [12]. This is unsurprising since the traditional focus of surveillance has been newly identified symptomatic patients. When WHO last published guidance on HBV surveillance, in 2003, that document addressed only acute viral hepatitis [13]. The importance of tracking chronic HBV and HCV infections is now more widely recognised due to increased awareness of the burden of disease and to the impact of better treatments on the long-term health of people with chronic HBV and HCV. However, it appears that surveillance systems in some WHO European Region Member States are not reflective of this transition.

Confirming the stage of $\mathrm{HBV}$ and $\mathrm{HCV}$ infection is known to be challenging. There is no robust marker of acute HCV infection, and for both HBV and HCV, a combination of serological and molecular tests are often required [10]. These can be less accessible in resource-limited settings. The 2009 ECDC survey showed that some EU/EEA countries were not able to differentiate between acute and chronic cases [12], and this has remained an important problem in EU/ EEA countries subsequent to the implementation of the ECDC's regional surveillance programme, especially for HCV $[14,15]$. Our survey did not ask directly if countries are able to distinguish effectively between acute and chronic infections and did not collect information on the case definitions used. The fact that five of 10 responding countries stated that their surveillance systems include undefined hepatitis cases indirectly suggests that countries' capacity to differentiate cases by disease stage may be limited and raises questions about the comparability and robustness of data across different WHO European Region Member States.

Case reporting is the core element of hepatitis surveillance, but it is known to provide a considerable underestimation of the true number of viral hepatitis cases [10]. Because viral hepatitis B and C infections are often asymptomatic, case reporting can be limited by testing practices and by lapses in the implementation of screening programmes. The hepatitis disease burden therefore can be assessed more accurately when case reporting is complemented by other sources of information including death registries, disease registries and serosurveys. Assessing the burden of disease from HBV and HCV is a highly complex undertaking. The most notable sequelae of chronic viral hepatitis - cirrhosis and liver cancer - are not exclusively attributable to HBV and HCV. At the same time, many people with $\mathrm{HBV}$ and $\mathrm{HCV}$ have comorbidities that might accelerate the development of complications of chronic infection $[16,17]$. The incorporation of data on conditions and outcomes associated with HBV and HCV into national surveillance allows for better assessment of the burden of disease and of temporal trends at the national level. However, the logistics of pooling data from multiple sources such as cancer registries, other disease registries and death certificate records is challenging even in countries with well-resourced 
health systems. It is encouraging to see that HBV and HCV surveillance in some of our study countries appears to encompass the gathering of information on key associated conditions and outcomes. At the same time, however, study findings suggest that associated conditions are not being thoroughly documented in the study countries as a whole.

Despite the major role of injecting drug use as a driver of the ongoing HBV and HCV epidemics in Europe [5], only half of the responding countries in our study reported having screening programmes for PWID. The 2009 ECDC survey indicated that a number of EU/EEA countries also lacked targeted screening programmes for PWID [12]. Across the 10 responding countries in our study, three other high-risk populations appeared to not be taken into account in many countries' screening efforts: inmates in closed settings, sex workers and MSM. A notable commonality among PWID, prison inmates, sex workers and MSM is that health systems often do not reflect their needs, in part because of the stigmatised nature of their activities. Our study findings raise the question of how this pattern might be impacting negatively on the response to HBV and HCV in some countries.

Furthermore, since our study did not ask respondents to provide quantitative information regarding populations screened for $\mathrm{HBV}$ and $\mathrm{HCV}$, it is not possible to assess the robustness of screening activities for specific populations. The implication of this data gap can be illustrated by considering responses to the survey question about whether people living with HIV are screened for HBV and HCV. Eight countries reported screening this population for HBV, and nine, for HCV. In any of those countries, a one-time initiative that tested a very small number of HIV-positive people might have been regarded by the survey respondent as 'screening' in that population. Considering the central role of some populations in the HBV and HCV epidemics in many countries, this is an issue that warrants more in-depth research. Future studies might ask countries to report quantitative details about how screening activities for HIV-positive people, PWID and other populations of interest inform national viral hepatitis programmes.

The European Parliament's recognition of specific gaps in individual countries, including any sort of mechanism for coordinated viral hepatitis surveillance, ultimately led to the introduction of 'enhanced surveillance' for HBV and HCV in EU/EEA Member States in 2011, with national governments being requested to submit surveillance data to a common dataset. The first data submission round was completed in September 2013, and ECDC researchers published the findings in late 2014 $[14,15]$. While it was recognised that the process of harmonising HBV and HCV surveillance across EU/EEA countries was far from complete, the data obtained in the first round still offered valuable insights about the region's HBV and HCV epidemics. The ECDC experience both demonstrates the feasibility of harmonisation across national surveillance systems and provides a functioning regional viral hepatitis surveillance system that might perhaps be expanded through collaboration with other stakeholders. It is thus an opportune time to explore the prospect of instituting harmonised HBV and HCV surveillance for the entire WHO European Region, which currently encompasses the 31 EU/EEA countries and 22 additional countries outside of the EU/EEA. Our study findings, by providing a snapshot of the features of some national surveillance systems outside of the EU/EEA, contributes to the evidence base that would be required to guide such an undertaking.

This study has a number of limitations in addition to those already identified. It was not designed to evaluate the quality of surveillance data collected, nor the extent to which the data collected are reliable and valid for following disease transmission and progression, but instead to describe key characteristics of surveillance systems and screening programmes. Further surveillance data analyses and surveillance system validation studies are needed to assess the utility and reliability of the current surveillance activities in the responding countries. Because of the low response rate, generalisations cannot be made about the study region as a whole, nor is it possible to draw conclusions from comparisons to other regions. Although the survey included brief definitions for many surveillancerelated terms, some terms were not defined, and survey questions may have been understood differently by respondents in different settings. Future surveys should define all terms employed.

Being restricted to using either the English or Russian language may have further affected how survey respondents understood and answered questions. Although carefully reviewed, the survey itself was not back-translated from Russian to English. Since there was no verification of information reported by country focal points, the accuracy of the data depends on whether these individuals answered all survey questions correctly. Finally, data for this study come from a survey carried out in 2012. Since that time, it is possible that the passage of the World Health Assembly's second resolution on viral hepatitis in 2014 [18] and the increasing attention given to viral hepatitis by the global public health community may have spurred some countries to make improvements to their viral hepatitis surveillance systems.

In conclusion, as momentum continues to build around the public health response to viral hepatitis at the national, regional and global levels, greater attention to national surveillance systems will be a prerequisite for obtaining suitable data to guide decision-making. This study indicates that some important components of viral hepatitis surveillance such as mandatory surveillance and the reporting of both acute and chronic $\mathrm{HBV}$ and HCV are in place in several European countries where little was previously known about the nature of surveillance efforts. At the same time, there is a clear 
need for additional research to illuminate key details about how surveillance is carried out in these and other European countries outside of the EU/EEA. The World Health Organization's first-ever global health sector strategy for viral hepatitis, adopted by the World Health Assembly on 28 May 2016, places viral hepatitis surveillance as one of the most important components of the strategic information framework, under the first of its five strategic directions: information for focused action [19]. It seems questionable whether progress under this strategy can be effectively measured in the WHO European Region without a cohesive effort to develop comprehensive and coordinated disease surveillance programmes in the Region. Our study, by providing a baseline overview of viral hepatitis surveillance and screening programmes in some European countries outside of the EU/EEA, contributes to the ECDC's work in this area and informs future plans to harmonise and enhance strategic information activities in the entire WHO European Region.

\section{${ }^{*}$ Erratum}

In the first sentence of the methods section, 'Bulgaria' was removed. This was corrected on 03 June 2016.

\section{Conflict of interest}

None declared.

\section{Authors' contributions}

All authors contributed extensively to the work presented in this paper. IE conceived of the study, and led in its design and coordination. JVL and KSH prepared the initial analysis of the data and first draft of the article. JVL oversaw the writing process. AM reviewed and revised the draft with input from IE. All authors read and approved the final manuscript.

\section{References}

1. GBD 2013 Mortality and Causes of Death Collaborators ; Global, regional, and national age-sex specific all-cause and cause-specific mortality for 240 causes of death, 1990-2013: a systematic analysis for the Global Burden of Disease Study 2013.Lancet. 2015;385(9963):117-71. DOI: 10.1016/S01406736(14)61682-2 PMID: 25530442

2. Hope VD, Eramova I, Capurro D, Donoghoe MC. Prevalence and estimation of hepatitis B and C infections in the WHO European Region: a review of data focusing on the countries outside the European Union and the European Free Trade Association. Epidemiol Infect. 2014;142(2):270-86. DOI: 10.1017/ So950268813000940 PMID: 23714072

3. Nelson PK, Mathers BM, Cowie B, Hagan H, Des Jarlais D, Horyniak D, et al. Global epidemiology of hepatitis B and hepatitis $C$ in people who inject drugs: results of systematic reviews. Lancet. 2011;378(9791):571-83. DOI: 10.1016/So1406736(11)61097-o PMID: 21802134

4. European Centre for Disease Prevention and Control (ECDC). Hepatitis B and C in the EU neighbourhood: prevalence, burden of disease and screening policies. Stockholm: ECDC, 2010.

5. Hahné SJ, Veldhuijzen IK, Wiessing L, Lim T-A, Salminen M, Laar M. Infection with hepatitis B and C virus in Europe: a systematic review of prevalence and cost-effectiveness of screening.BMC Infect Dis. 2013;13(1):181. DOI: 10.1186/14712334-13-181 PMID: 23597411

6. Mühlberger N, Schwarzer R, Lettmeier B, Sroczynski G, Zeuzem S, Siebert U. HCV-related burden of disease in Europe: a systematic assessment of incidence, prevalence, morbidity, and mortality.BMC Public Health. 2009;9(1):34. DOI: 10.1186/1471-2458-9-34 PMID: 19161623

7. World Health Organization (WHO). Public health surveillance Geneva: WHO. [Accessed 27 May 2015]. Available from: http:// www.who.int/topics/public_health_surveillance/en/

8. Nsubuga P, White ME, Thacker SB, Anderson MA, Blount SB, Broome CV, et al. Public Health Surveillance: A Tool for Targeting and Monitoring Interventions. In: Jamison DT, Breman JG, Measham AR, Alleyne G, Claeson M, Evans DB, et al., editors. Disease Control Priorities in Developing Countries. 2nd ed. Washington (DC): World Bank; 2006. [Accessed 27 May 2015]. Available from: http://www.ncbi.nlm.nih.gov/books/ NBK11770/

9. Committee on the Prevention and Control of Viral Hepatitis Infection; Board on Population Health and Public Health Practice; Institute of Medicine. Hepatitis and liver cancer: a national strategy for prevention and control of hepatitis $B$ and C. Washington, DC: The National. Academies Press; 2010. Available from: http://www.nap.edu/catalog/12793.html

10. Wiktor SZ. Where next for hepatitis B and C surveillance?J Viral Hepat. 2015;22(7):571-3. DOI: 10.1111/jvh.12400 PMID: 25754464

11. Rantala M, van de Laar MJW. Surveillance and epidemiology of hepatitis B and C in Europe - a review.Euro Surveill. 2008;13(21):18880.PMID: 18761967

12. Duffell EF, van de Laar MJ. Survey of surveillance systems and select prevention activities for hepatitis B and C, European Union/European Economic Area, 2009. Euro Surveill. 2015;20(13):17-24. DOI: 10.2807/1560-7917.ES2015.20.13.21080 PMID: 25860392

13. World Health Organization (WHO). WHO-recommended standards for surveillance of selected vaccine-preventable diseases. Geneva: WHO; 2003.

14. Duffell EF, van de Laar MJW, Amato-Gauci AJ. Enhanced surveillance of hepatitis B in the EU, 2006-2012.J Viral Hepat. 2015;22(7):581-9. DOI: 10.1111/jvh.12364 PMID: 25417854

15. Duffell EF, van de Laar MJW, Amato-Gauci AJ. Enhanced surveillance of hepatitis C in the EU, 2006 - 2012.J Viral Hepat. 2015;22(7):590-5. DOI: 10.1111/jvh.12367 PMID: 25420699

16. Andreoni M, Giacometti A, Maida I, Meraviglia P, Ripamonti D, Sarmati L. HIV-HCV co-infection: epidemiology, pathogenesis and therapeutic implications.Eur Rev Med Pharmacol Sci. 2012;16(11):1473-83.PMID: 23111959

17. Punzalan CS, Bukong TN, Szabo G. Alcoholic hepatitis and HCV interactions in the modulation of liver disease.J Viral Hepat. 2015;22(10):769-76. DOI: 10.1111/jvh.12399 PMID: 25754333

18. Sixty seventh World Health Assembly. WHA67.6 Hepatitis. 2014. Available from: http://apps.who.int/gb/ebwha/pdf_files/ WHA67/A67_R6-en.pdf

19. World Health Organization (WHO). Development of the Global Health Sector Strategy on viral hepatitis, 2016-2021. Geneva: WHO. Available from: http://www.who.int/hiv/mediacentre/ news/hepstrategy2016-21/en/

\section{License and copyright}

This is an open-access article distributed under the terms of the Creative Commons Attribution (CC BY 4.0) Licence. You may share and adapt the material, but must give appropriate credit to the source, provide a link to the licence, and indicate if changes were made.

This article is copyright of the authors, 2016. 